\title{
Eam \\ Challenges in the Teaching of Sociology in Higher Education. Contributions to a Discussion
}

\author{
Carlos Miguel Ferreira ${ }^{1, *}$ and Sandro Serpa ${ }^{2}$ \\ 1 Interdisciplinary Centre of Social Sciences-CICS.NOVA, Polytechnic Institute of Castelo Branco, \\ Estoril Higher Institute for Tourism and Hotel Studies, 1069-061 Lisbon, Portugal \\ 2 Department of Sociology, Faculty of Social and Human Sciences, University of the Azores, \\ Interdisciplinary Centre of Social Sciences-CICS.UAc/CICS.NOVA.UAc, and Interdisciplinary Centre for \\ Childhood and Adolescence-NICA-UAc, 9501-801 Ponta Delgada, Portugal; sandro.nf.serpa@uac.pt \\ * Correspondence: cmiguelferreira@ipcb.pt
}

Received: 29 July 2017; Accepted: 21 October 2017; Published: 31 October 2017

\begin{abstract}
At a time when Sociology (either in its introductory or general dimension or in the form of specialised Sociologies) is acknowledged as a scientific discipline with important contributions in training at the higher education level, and not only for the future sociologist, there is a need to (re)think the problem of teaching Sociology in this context. This article seeks to contribute to this discussion on the teaching of Sociology in higher education, being a grounded reflection that is based on the authors' teaching experience in the Portuguese context. Sociology has specificities, which we put forward through four framing principles, namely the need to permanently mobilise sociological imagination, be multi-paradigmatic, the need to be receptive to a heuristic interdisciplinarity, and, finally, foster reflexivity at several levels. These principles should, from our standpoint, shape the teaching of Sociology, both delimiting what should be taught and fostering the way to teach while abiding by these principles. As a conclusion, this problem of teaching Sociology needs an in-depth investigation, in the search for a growing pedagogical quality in a context of increasing opportunities to reform the type of teaching provided in higher education, which is a permanent challenge.
\end{abstract}

Keywords: teaching Sociology; training in Sociology; sociologist; higher education; framing sociology principles

\section{Introduction}

This article seeks to reflect on a relevant component of Sociology: that of training, based on the experiences of the teaching of Sociology by its authors in several higher education programmes in Portugal. Favouring, in this component, the teaching and learning processes, the article seeks to develop a reflection on how these processes may be successful in affirming the sociological perspective in student training in the higher education context. The attainment of this goal implies, on the one hand, that Sociology is articulated in an interdependent way as training with other components of Sociology: Sociology as science and Sociology as profession [1]; on the other hand, it involves the emphasis on a reflective epistemological conception of Sociology in relation to various interdisciplinary contributions.

As science, Sociology (either in its introductory or general dimension or in the form of specialised sociologies) is generally acknowledged, to a greater or lesser extent, as a scientific discipline that perceives in its specific way the social reality, producing plural theoretical topics, formulating research problems within the context of these topics, and developing methodical strategies that guide empirical research. In the component of Sociology as profession, we highlight the diversity of professional roles and practices in Sociology, the processes of constitution of sociologists as a professional group, their forms of professional association, and models of professional culture (e.g., in the Portuguese 
context, [2-4]). Specifically in the models and practices of training in Sociology, which are articulated with these science and profession components, several elements are relevant and may be the object of analysis, such as the structure of the programmes and courses, course syllabuses, teachers qualifications and competences, and teaching/learning activities developed, among others.

Sociology, as a privileged scientific space for (self)reflection on its own activity and the resulting product, contributes to a specialised knowledge with the limitations that this entails; thus, it is important, on the one hand, to foster a sociological perspective that spurs, in the process of construction and analysis of its objects, the influence of cultural, economic, and political aspects, and, on the other hand, which encourages the dialogue with other disciplinary and scientific spaces.

At present, the legitimacy of Sociology is evident also in Portugal, both through a scientific and academic dimension and through a social recognition dimension [3,5]. For this institutionalisation of Sociology, teaching, particularly in higher education, is crucial in the legitimacy and reproduction of Sociology, not only in Portugal [5,6], but also in other countries [7,8], albeit this is not a universally shared situation [9]. In this context that acknowledges the importance of the contribution of Sociology in higher education programmes, while, "in the past, teaching sociology was a political act, a way of staking a claim for an emergent discipline. In the contemporary higher education context, publicly and expressly caring about teaching sociology can be read as a radical and ethical stance" [8] (p. 394).

As a result of all this, being Sociology a science with its own specificities, the question arises as to how to successfully teach Sociology in higher education, whether in Sociology programmes or in other programmes.

So as to fulfill this aim, this article emphasises an analysis on the centrality of the specific principles of quality Sociology teaching at the higher education level, developing contributions for a reflection that contextualises some features of sociological science that must be involved in this teaching and learning process, which seem to be central to the success of this process and with increasing quality.

\section{Sociology in Higher Education}

\subsection{Framing Principles of What to Teach}

The component of Sociology as a science refers to a specific set of cognitive criteria and tools, accrued knowledge, and research practices, being the main basis from which Sociology as training and Sociology as profession components are developed [1]. But, what is Sociology? There is a wide array of definitions and it is not easy to define it in a direct way. According to common sense, Sociology deals with the study of society or of the social [10]. In a generally accepted synthesis, Sociology seeks to explain the social through another social phenomenon [11], intersecting substantive theories with epistemological and methodological procedures.

As a first framing principle of what to teach, Sociology stands forth as a science that demystifies common knowledge shared in society, but which is, in reality, not correct [12,13], and that fosters sociological imagination [14], given that "Sociology is about seeing with a new pair of eyes; unlearning and relearning much of what we take for granted about society" [15] (p. 872). This is reinforced by the Portuguese Sociological Association when it states, in its Code of Ethics, that sociologists should seek to achieve the highest possible objectivity in the analysis of social reality [16]. To this, social familiarity is added $[9,11,17]$, which, if not properly worked, may be an (additional) factor of hindrance in the understanding of Sociology, thus making it difficult to desacralize some students' views [18-20]. This deconstruction of students' preconceived ideas has to be carried out in a context in which the understanding of the curricular structure where the curricular unit is inserted is critical for the definition of the pedagogical strategies to be developed and that are also dependent on the centrality and consequent legitimacy ascribed to the sociological science in the educational level under consideration [13,21-23].

As a second principle, it is sought that students understand Sociology as a multi-paradigmatic science, and this factor is inherent either in the introduction to Sociology or in specialised Sociologies. 
It is relevant to demonstrate students that the processes of knowledge name and qualify social reality at the very moment of analysis and that the disciplines establish dimensions of that reality when they analyse it. The plurality of social sciences results, on the one hand, from the real complexity of human action that requires complex analytical levels and elaborations, and, on the other hand, from the approximate and piecemeal nature of scientific knowledge that denies the possibility of a unitary knowledge of the real [24]. The deontological sense in teaching is verified in this respect by the theoretical and methodological plurality that makes up Sociology $[16,25,26]$. This assumption is reinforced in the International Sociological Association's (ISA) Code of Ethics: “The principles of openness, criticism and respect for all scientific perspectives should be followed by sociologists in their teaching and professional practices" [27].

The emphasis on teaching is, thus, placed on a sociological perspective that is focused on the theoretical pluralism of Sociology. This pluralism seeks to articulate macro-social dynamics with local processes, allowing the linkage between subjective significances and practices, and focusing on the articulations between systems and actors, between structures and practices, between the reality of the social conditions of existence and the social construction of reality [22,28-30]. The respect for this pluralism is shaped by a conception of social/individual relationships that excludes unilateral and dogmatic responses. Pluralism consists of respecting different sociological orientations and mobilising them according to the intelligibility they bring to a precise phenomenon [31,32].

As a third principle, the teaching of Sociology advocates a perspective that emphasises a relationship of interdependence and complementarity between social sciences, which is fundamental in the understanding of the complexity of social reality, albeit the boundaries between each of the social sciences are uncertain and floating, as they envisage distinctively the same social reality. It is maintained that social reality is one and indivisible, and is, therefore, viewed and analysed as a whole, being the real object of all social sciences. As sustained by Silva and Pinto [24], each social science has a specific perspective on social reality and is characterised by producing its theoretical topic; by producing research problems in the context of that topic; by constructing sets of principles, theories, methodical strategies, and crucial results that serve as a model or guideline for research-paradigms. It is sought to demonstrate that the social is irreducible to the individual and that without the consolidation of this thesis there would be no social sciences. Social reality is indivisible and social phenomena are total social phenomena (Mauss). All facts are always complex and multidimensional and may be grasped from different perspectives.

In sum, Sociology distinguishes from other social sciences by its particular way of capturing and interrogating the concrete social real, developing appropriate theories, methods, and techniques; there is the need to apprehend and to learn them in a grounded way, as a specific scientific discipline with its autonomy [33]. Thus, the teaching of Sociology focuses on the assertion of a straightforward and reflexive disciplinarity [25] that incorporates interdisciplinary contributions in its analyses and reflections [30].

Finally, and as the fourth principle, Sociology, as scientific knowledge, sustains itself as a reflexive science whose purpose it is to critically analyse what it does at various levels (its possibilities, its limits, its procedures), so as to assess the conditions in which it does so, as well as the effects of its activity [17], given that Sociology studies and is part of society. The knowledge of Sociology is permanently assimilated by society, influencing it in a "dynamic cyclicity" [17] (p. 118), as a permanently unfinished enterprise [9]. Sociology not only studies society but is also a part of society. Sociology has something relatively specific in relation to other disciplinary-professional fields: an acute sociological self-awareness, a permanent sociological self-reflexivity on Sociology as social practice and system of representations, stage of conflicts of interests and games of power, on the practice of Sociology as a socially conditioned scientific and professional activity, socially produced, and always with social consequences [17].

The teaching of Sociology seeks to provide students with the potentialities of this reflexivity, that is, the capacity of individuals and groups to reflect about themselves and about others. This capacity 
institutes the domain of the symbolic and becomes effective insofar as it provides cognitive and representational elements of adequacy to reality. The knowledge and representations that people, groups, and societies have and use, often referred to as "common sense", is, in modern societies, increasingly shaped by social sciences. This social appropriation of the knowledge developed by social sciences has a return effect by provoking a permanent re-thinking about conceptual topics and elaborations [34].

It is sought that students identify types of social reflexivity, namely (i) technical reflexivity, in which the knowledge of social scientists (or their clients) is used to modify reality in a conscious manner; (ii) mediate reflexivity, in which the knowledge produced by social scientists is applied to social reality by the same actors who participate in that knowledge through its diffusion in common knowledge via mass media, higher education, and other channels of knowledge dissemination and diffusion; and (iii) immediate reflexivity, in which the origin of knowledge lies in the actors themselves, who are subjects and not objects of the process of knowledge use [35] (p. 607).

After having put forward and discussed the four framing principles of what to teach, the core question of this article is raised: how to implement them? This issue is addressed over the next section.

\subsection{Guidelines on How to Teach}

In what regards the guidelines on how to teach Sociology in higher education, the real situation regarding the social [9], the institutional and the legitimacy framework of this teaching of Sociology plays a major role $[21,23,36-38]$.

The teaching of Sociology in programmes where it is part of the central disciplinary core presents greater opportunities for legitimacy and investment than in those where its location is peripheral or secondary, being this peripherality a great challenge in the pedagogical relationship [21]. In the teaching of Sociology in programmes other than Sociology ones, it is sometimes seen by students as a "cafe table science" [39]. Paradoxically, according to a recent study carried out in Portugal, in the areas of natural or technological sciences, Sociology is relatively welcomed, whereas, in areas that could be supposed to be closer, in arts and humanities or in social sciences, there are instances of a certain devaluation of its relevance [39].

Concomitant to the legitimacy of Sociology in each specific institutional context, the clear and consistent demarcation of sociological competences has a central relevance to Sociology teaching/learning processes [1,22]. Specifically on Sociology as training, it is critical to define, in a clear and unambiguous way, what is expected to be promoted with the teaching of Sociology in each specific institutional context, in what can be a difficult consensus [37]. In Egreja's [39] research, faculty and programme directors highlight, as core competences that they would like students to develop: critical and reflexive capacity; the break with common sense; the acquisition of a perspective of the areas of study as social phenomena; the development of writing and reading, group work, and oral presentation skills; and, less frequently, the development of inter-relational competences.

For the purposes of this paper, which seeks to present a generic perspective, Ferguson's proposal [22] (pp. 171-172) is worth considering, due to its clarity and pertinence. The author proposes, in a synthesis, the following Toolbox in the Sociological Literacy Framework as essential sociology learning outcomes: apply sociological theories to understand social phenomena; critically assess explanations of human behavior and social phenomena; apply scientific principles to understand the social world; evaluate the quality of social scientific methods and data; rigorously analyse social scientific data; and, use sociological knowledge to inform policy debates and promote public understanding. To these, we may add, in a general way, the development of reflexivity and critical thinking competences [9].

It is critical to reinforce a set of learning processes explicitly oriented towards the effective and consistent attainment of sociological competences. In the case of specific training for the sociologist, this actor, in the exercise of his/her profession, needs to demonstrate four types of competences as capacities for effective activation of general knowledge in particular contexts [1] (p. 56): (i) theoretical 
competences (ability to select, apply, and produce theories and concepts that are adequate to the objects and problems concerned); (ii) methodological competences (relevant use and development of methods and techniques for collecting and analysing empirical information on social relationships and processes); (iii) relational competences (expert ability to act in the social interactions involved in the objects of sociological work, in a manner that is shaped by sociological knowledge); and (iv) operating competences (ability to select, activate and create a varied set of procedures of technical, strategic, organisational, or communicational action, developed or re-worked by sociologists in multiple fields). Such capacity is particularly important for the training in Sociology, but to some extent, for all to have some insight and a few, although incipient, sociological competences [1].

A third guideline for the success in teaching regards the fact that the teacher considers and respects, within reason, students' features ([40]; in a critical perspective of the transformative agenda of social justice, see [41]). A basic principle of successful teaching in Sociology is the mobilisation of the student's experience and knowledge [26,42,43]. According to Egreja [39], teachers state that the difficulties that usually arise in the teaching of the discipline are the lack of writing and reading habits on the part of students, their low level of general culture, and immaturity, which has been increasing from year to year. Thus, there is the need to adapt, as appropriate, teaching strategies to the students' traits (e.g., age, gender, ...). Students should not, then, be treated as sheer passive consumers, and it is important to consider the social context in which the teaching-learning process takes place [44], as well as elements such as social dynamics and interactions that are established in this teaching-learning process, the power relationships in the established interactions and their translation into the curriculum itself, and the organisational context [8,44].

It is, thus, important for teachers to know their audience, in addition to knowing the contents (what we take for granted) [20], so as to be receptive to students' questions [13], not forgetting the importance of the teacher-student interactivity [25], as privileged moments for the development of a sociological stance [26], in particular because in those moments it is possible to create the conditions for those who, in the context of large classes, never express themselves to do so [25].

However, it should be considered that the use of teaching methods other than lectures implies constraints, but also advantages, namely the participation and the teacher-student interaction. The possibility of making students' representations and ideas more explicit is also worth highlighting, thus, enabling, "an exercise of questioning that reveals the scientific weaknesses of such an argument" [13] (p. 148). This questioning may even, in certain situations, take place in a context of emotional discomfort within the classroom [45].

Similarly, another orientation is the use of varied teaching strategies, and, if possible, with the support of technologies that can greatly benefit the quality of teaching achieved, boosting a greater dynamism in the classes that are considered by students, sometimes, as very expositive and theoretical lectures [39]. However, according to literature, it seems relevant to not start from the assumption that either teachers or students are necessarily digital literates; hence, the need arises to promote digital learning in higher education [46-49].

Other varied pedagogies are particularly relevant, such as newspapers, films, etc., whose use seeks the growing informed participation of students [26,39], or even fiction [50], as well as, whenever possible, some empirical research in the learning of Sociology through empirical research [25]. This relevance is linked to the fact that the capacities in Sociology are attained and developed through concrete training and continuous exercise, bearing in mind that the training in Sociology exclusively focused on the theoretical and methodological knowledge does not privilege the "appropriate processes of the shift to practice"; rather, it promotes a "limited apprehension of contents, carried out only at the discursive level" [1] (p. 57).

Thus, it is relevant, whenever possible and respecting the context in question, to favour an active students' assessment that promotes their autonomy and that is itself "a learning tool" (Dochy \& McDowell, 1997 cit. in [51], p. 212) through the provision of timely and (self)regulatory feedback [51]. 
Key features of active learning-discussions and exchanges, questions, improvisations, and off-the-map developments - ensure that learners actively participate in knowledge creation rather than simply passively consume information. When students reflectively engage by talking about what they know, questioning what they don't, and interacting with instructors and peers, they develop the ability to understand and apply what they have learned [52] (p. 251).

This active teaching and research have also to be framed in the features of the programme, organisation and class:

Active, collaborative learning and other high-impact practices may not work well in all places or with all students, but in any case, instructors must hold up their end of the bargain by questioning their assumptions and adjusting their pedagogy and assessment accordingly [53] (p. 213-214).

Finally, the teaching of Sociology favours a certain (controlled) flexibility on the part of the teacher. Likewise, the receptivity of the teacher to the possibility of change is very important [42,52], fighting excessive isolation that can be harmful to the quality of teaching [36]. Indeed, it is critical that the teacher has a self-reflexive and self-assessing capacity, both during class and in the longer term, in seeking to foster an improvement of his/her teaching processes: "It is crucial for teachers to question regularly, reflect upon, and improve their teaching practices" [54] (p. 15).

\section{Opportunities and Challenges to Enrich the Teaching of Sociology}

Teaching, notwithstanding being a crucial dimension in higher education [8,55], has been a less recognised dimension of the teacher's work, both internally and externally to higher education institutions $[7,56]$. However, greater emphasis is increasingly placed on quality, effectiveness and efficiency of this teaching, and innovation and excellence are promoted [7,57].

Despite tending to be a conservative setting, pedagogical innovation in higher education seems to be increasingly fostered by the need felt by academics and their institutions, but also by the pressure from social and political stakeholders, as well as by scientific and technological changes [49,58-60]: "In a complex socio-political-economic academic context, pedagogical innovation unquestionably prevails as one of the solutions to the challenges faced by today's university" [60] (p. 71). As Alhija [61] summarises in a very pertinent way:

Higher education institutions engage in advancing good teaching for various reasons. First, they are interested in demonstrating that they are reliable providers of good quality education, while serving multiple stakeholders with different expectations. Second, they are required to respond to the increasing demand for meaningful and relevant teaching. Students as well as employers and policy makers want to assure that education will prepare students for rewarding employment and for professional growth over a lifespan. Third, research performance is no longer sufficient to maintain the reputation of the higher education institutions and balancing performance on teaching and learning achievements with research performance has become essential [61] (p. 4).

Although it sometimes seems easy, teaching is a difficult task [55]. This work is highly complex and affected by countless causes, being, under different circumstances, some of these factors more or less controlled by the teacher. In this teaching process, self-confidence, experience, and content knowledge, although not being unique elements, seem to take on a high centrality in the choice of the structure and the pedagogical method by the teacher and in the consequent higher learning success. It seems that the higher the confidence resulting from experience and content knowledge, the higher the likelihood of a more successful interaction with students; the teacher receives more feedback 
from them, thus reducing the teacher-centred approaches [43] and taking risks trying new ways of teaching [62].

In higher education teaching, the need for a teaching process that is more focused on student learning than on lecture teaching through a teaching process that promotes active learning is increasingly recognised [58-60]. For the impetus of this active learning in the teaching in higher education, it is important to consider more general areas of concentration, such as, among others: 1. have knowledge of the teaching context (know the culture of the organisation; frame the objectives and their contents in the training/programme in question; have a basic knowledge of the class; make the articulation with other curricular units, if pertinent data); 2. demonstrate scientific knowledge (promote the permanent update; have mastery of theories and methodologies to be taught); and 3. have pedagogical flexibility (make a clear and non-inflexible planning; demonstrate self-reflection and self-assessment capacities; show responsiveness to questions; promote practical exercises; use relevant but varied teaching methodologies; foster a balanced motivation; have the ability for some improvisation; encourage an active and diverse student assessment); besides an array of other elements.

However, in addition to these general areas of concentration that seem to be implicated in a higher quality and relevant higher education teaching, specifically in the teaching of Sociology, sociologists must consider the specific nature of the teaching practice and the competences required to teach $[16,20]$. In particular to the teaching of Sociology, it is certain that "the acquisition of the disposition to teach is not immediate or mechanical" [18] (p. 20); some competences or requirements to be considered in the sociologist teacher seem to be essential for a Sociology teacher to be successful in teaching this science.

In this context, and after the previous exposition, it seems that fulfilling the aim to teach Sociology in higher education with increasing quality and relevance implies considering and fostering the four principles previously set forth, which are specific to the teaching of Sociology in higher education and interact among themselves. From these, sociological imagination, multi-paradigmatic science, heuristic interdisciplinarity, and (self)reflexivity are to be emphasised. The application of these four principles may motivate a teaching of Sociology with growing relevance. It was in the respect for this more general observation that we presented, in this reflection, some guidelines that are inter-influenced (the degree of legitimacy of Sociology in the institutional and curricular context in question; the definition of competences to be attained by students; the consideration and respect, as far as possible, for students' traits; content mastery, varied teaching strategies, complementary with active work on the part of students; and, the need for some controlled flexibility on the part of the teacher) that seem to be central and fundamental for the development of a well achieved teaching of Sociology.

\section{Conclusions}

This analysis of general and specific aspects of the teaching of Sociology in higher education reveals that no pedagogical technique may be considered the best and universal one, as Guerreiro already mentioned in 1987 [20]. It is critical to have "an integrated vision of teaching science and art" [40] (p. 2), so as to attain a balance in finding the best conditions for success:

The teacher is unlikely to be an effective teacher-especially at the level of higher education-without complex interactions both between the teacher and the students and between the students. It has long been held that the concept of teaching necessarily entails learning; what is beginning to become evident is that, in practice, the work of the teacher in higher education cannot be satisfactorily understood without a grasp of its related structures of dialogue and communication. Skilled teaching calls for the most intricate of communicative interactions if learning is going to be fully encouraged and promoted [63] (p. 86). 
In this complexity, the students' assessment process itself can have profound implications, not only for their learning but also in other dimensions, such as the image of the institution and the programme, as well as in the teacher's own professional path $[7,29]$.

The teaching of Sociology in higher education is a permanent challenge, a work of Sisyphus that is never concluded, with answers created according to each situation. This article, as a further contribution to this discussion, assumes that this topic needs to be investigated in an in-depth way considering its importance, insofar as "we all have something to gain when sociologists take time to discuss their teaching, their learning outcomes, and the best interests of their students in higher education" [22] (p. 174).

Acknowledgments: University of Azores, Interdisciplinary Centre of Social Sciences-CICS.UAc/CICS.NOVA.UAc, UID/SOC/04647/2013, with the financial support of FCT/MEC through national funds and when applicable co-financed by FEDER under the PT2020 Partnership Agreement. The authors acknowledge the comments and suggestion by this article's editor and three anonymous reviewers.

Author Contributions: All authors had equal contributions to this paper.

Conflicts of Interest: The authors declare no conflict of interest. The funding sponsors had no role in the design of the study; in the collection, analysis or interpretation of data; in the writing of the manuscript, and in the decision to publish the results.

\section{References}

1. Costa, A.F. Será a sociologia profissionalizável? [Is sociology possible to professionalize?]. In Sociologia no Ensino Superior: Conteúdos, Práticas Pedagógicas e Investigação [Sociology in Higher Education: Contents, Pedagogical Practices and Research], Proceedings of the Meeting Sociologia no Ensino Superior: Conteúdos, Práticas Pedagógicas e Investigação [Sociology in Higher Education: Contents, Pedagogical Practices and Research], Porto, Portugal, 6-7 December 2002; Gonçalves, C.M., Rodrigues, E., Azevedo, N., Eds.; School of Humanities of the University of Porto: Porto, Portugal, 2004; pp. 35-58.

2. Carreira, H.; Freitas, F.; Valente, I. (Eds.) Profissão Sociólogo [Profession Sociologist]; Celta Editora: Oeiras, Portugal, 1999.

3. Neto, H.V. Principais estádios evolutivos da sociologia em Portugal [Main evolutionary stages of sociology in Portugal]. Sociologia 2013, XXVI, 37-59.

4. Costa, A.F. Cultura profissional dos sociólogos [Professional culture of sociologists]. Sociol. Probl. Prát. 1988, 5, 107-124.

5. Gonçalves, C.M.; Rodrigues, E.; Azevedo, N. (Eds.) Sociologia no Ensino Superior: Conteúdos, Práticas Pedagógicas e Investigação [Sociology in Higher Education: Contents, Pedagogical Practices and Research]. In Proceedings of the Meeting Sociologia no Ensino Superior: Conteúdos, Práticas Pedagógicas e Investigação [Sociology in Higher Education: Contents, Pedagogical Practices and Research], Porto, Portugal, 6-7 December 2002; School of Humanities of the University of Porto: Porto, Portugal, 2004.

6. Almeida, A.N. Uma introdução: Sociologia, sociólogos e práticas profissionais. Percursos de construção da identidade no Portugal democrático [An introduction: Sociology, sociologists and professional practices. Paths of identity construction in the democratic Portugal]. In Profissão Sociólogo [Profession Sociologist]; Carreiras, H., Freitas, F., Valente, I., Eds.; Celta Editora: Oeiras, Portugal, 2009; pp. 1-10.

7. O'Sullivan, S. Teaching sociology in an age of teaching 'excellence'. Ir. J. Soc. 2016, 24, 34-53. [CrossRef]

8. Harley, K.; Natalier, K. Teaching sociology—Reflections on the discipline. J. Soc. 2013, 49, 389-396. [CrossRef]

9. Miskolczi, P.; Király, G. Teaching society? Looking for new ways to teach Sociology in contemporary Hungary. Družboslovne Razpr. 2016, 32, 83, 63-81.

10. Elliot, A.; Turner, B.S. Debating "the Social": Towards a critique of sociological nostalgia. Societies 2012, 2, 14-26. [CrossRef]

11. Javeau, C. Lições de Sociologia [Lessons of Sociology]; Celta Editora: Oeiras, Portugal, 1998.

12. Elias, N. Introdução à Sociologia [Introduction to Sociology]; Edições 70: Lisboa, Portugal, 2008. 
13. Vieira, M.M. Converter incrédulos: A sociologia na cidade das ciências duras [Converting skeptics: Sociology in the city of hard sciences]. In Sociologia no Ensino Superior: Conteúdos, Práticas Pedagógicas e Investigação [Sociology in Higher Education: Contents, Pedagogical Practices and Research], Proceedings of the Meeting Sociologia no Ensino Superior: Conteúdos, Práticas Pedagógicas e Investigação [Sociology in Higher Education: Contents, Pedagogical Practices and Research], Porto, Portugal, 6-7 December 2002; Gonçalves, C.M., Rodrigues, E., Azevedo, N., Eds.; School of Humanities of the University of Porto: Porto, Portugal, 2004.

14. Mills, C.W. The Sociological Imagination; Oxford University Press: Oxford, UK, 1959.

15. Hjelm, T. Empowering discourse: Discourse analysis as method and practice in the sociology classroom. Teach. High. Educ. 2013, 18, 871-882. [CrossRef]

16. Associação Portuguesa de Sociologia (APS) [Portuguese Association of Sociology]. Código Deontológico [Code of Ethics], 1992. Available online: https://www.aps.pt/pt/codigo-deontologico (accessed on 29 October 2017).

17. Costa, A.F. Sociologia [Sociology]; Difusão Cultural: Lisbon, Portugal, 1992.

18. Bívar, A. Nome, nomeado, seja feita a nossa vontade [Name, nominee, may our will be done]. In Profissão Sociólogo [Profession Sociologist]; Carreiras, H., Freitas, F., Valente, I., Eds.; Celta Editora: Oeiras, Portugal, 1999; pp. 19-31.

19. Massengill, R.P. Sociological writing as higher-level thinking: Assignments that cultivate the sociological imagination. Teach. Sociol. 2001, 39, 371-381. [CrossRef]

20. Guerreiro, M.D. Questões pedagógicas no ensino da sociologia [Pedagogical issues in the teaching of sociology]. Sociol. Probl. Prát. 1987, 3, 51-65.

21. Esteves, A.J. Métodos, práticas pedagógicas e públicos da sociologia: Um ponto de vista situado [Methods, pedagogical practices and public of sociology: A situated point of view]. In Sociologia no Ensino Superior: Conteúdos, Práticas Pedagógicas e Investigação [Sociology in Higher Education: Contents, Pedagogical Practices and Research], Proceedings of the Meeting Sociologia no Ensino Superior: Conteúdos, Práticas Pedagógicas e Investigação [Sociology in Higher Education: Contents, Pedagogical Practices and Research], Porto, Portugal, 6-7 December 2002; Gonçalves, C.M., Rodrigues, E., Azevedo, N., Eds.; School of Humanities of the University of Porto: Porto, Portugal, 2004; pp. 61-77.

22. Ferguson, S.J. The center does hold: The sociological literacy framework. Teach. Sociol. 2016, 44, $163-176$. [CrossRef]

23. De Carvalho Filho, J.L. O ensino de sociologia como problema epistemológico e sociológico [The teaching of sociology as an epistemological and sociological problem]. Educ. Real. 2014, 39, 59-80. [CrossRef]

24. Silva, A.S.; Pinto, J.M. Uma visão global sobre as ciências sociais [An overview of social sciences]. In Metodologia das Ciências Sociais [Methodology of Social Sciences], 8th ed.; Silva, A.S., Pinto, M., Eds.; Edições Afrontamento: Porto, Portugal, 1986; pp. 9-27.

25. Machado, F.L. Quatro princípios para o ensino da Sociologia [Four principles for the teaching of sociology]. In Sociologia no Ensino Superior: Conteúdos, Práticas Pedagógicas e Investigação [Sociology in Higher Education: Contents, Pedagogical Practices and Research], Proceedings of the Meeting Sociologia no Ensino Superior: Conteúdos, Práticas Pedagógicas e Investigação [Sociology in Higher Education: Contents, Pedagogical Practices and Research], Porto, Portugal, 6-7 December 2002; Gonçalves, C.M., Rodrigues, E., Azevedo, N., Eds.; School of Humanities of the University of Porto: Porto, Portugal, 2004; pp. 115-120.

26. Dourado, I.P. Mediação didática no ensino superior-Inventividade, níveis de abstração e o uso da metáfora como recurso didático no ensino de sociologia [Didactic mediation in higher education-Inventiveness, levels of abstraction and the use of metaphor as didactic resource in the teaching of sociology]. Rev. Bras. Ensino Super. 2016, 2, 34-45. [CrossRef]

27. International Sociology Association (ISA). Code of Ethics. 2001. Available online: http:/ /www.isa-sociology. org/en/about-isa/code-of-ethics / (accessed on 29 October 2017).

28. Dubar, C. Le pluralisme en sociologie: Fondements, limites, enjeu [Pluralism in sociology: Foundations, limits, stakes]. Socio-Logos 2006, 1. Available online: http:/ / socio-logos.revues.org/20 (accessed on 29 March 2008).

29. Sethuraju, N.; Prew, P.; Abdi, A.; Pipkins, M. The consequences of teaching critical sociology on course evaluations. SAGE Open 2013, 1-15. [CrossRef]

30. Morrison, A. A sociologist teaches history: Some epistemological and pedagogical reflections. Educ. Stud. 2017, 53, 233-246. [CrossRef]

31. Berthelot, J.M. L'Intelligence du Social [The Intelligence of the Social]; PUF: Paris, France, 1992. 
32. Berthelot, J.M. Os novos desafios epistemológicos da sociologia [The new epistemological challenges of sociology]. Sociol. Probl. Prát. 2000, 33, 111-131.

33. Haynes, A. In support of disciplinarity in teaching sociology: Reflections from Ireland. Teach. Sociol. 2017, 45, 54-64. [CrossRef]

34. Almeida, J. (Ed.) Introdução à Sociologia [Introduction to Sociology]; Universidade Aberta: Lisbon, Portugal, 1994.

35. Espinosa, E.L.; García, J.M.; Albero, C.T. La Sociología del Conocimiento y de la Ciencia [The Sociology of Knowledge and Science]; Alianza Editorial: Madrid, Spain, 1994.

36. Mårtensson, K.; Roxå, T. Peer engagement for teaching and learning: Competence, autonomy and social solidarity in academic microcultures. Uniped 2016, 39, 131-143. [CrossRef]

37. Greenwood, N.A. Toward publicly responsive sociology curricula: The role of introductory sociology. Teach. Sociol. 2013, 41, 232-241. [CrossRef]

38. Kapitulik, B.P. Teaching sociology in community college: Balancing ideals with institutional constraints. Am. Sociol. 2013, 44, 366-377. [CrossRef]

39. Egreja, C. O ensino da sociologia em cursos superiores de outras áreas de formação: A perspetiva de docentes e diretores [The teaching of sociology in higher education programmes in other educational areas: The perspective of faculty and directors]. Sociol. Probl. Prát. 2016, 82, 125-143. [CrossRef]

40. Arends, R.I. Aprender a Ensinar [Learning to Teach]; McGraw-Hill: Lisbon, Portugal, 1995.

41. Bassey, M.O. Culturally responsive teaching: Implications for educational justice. Educ. Sci. 2017, 6, 35. [CrossRef]

42. Pedersen, D.E. Active and collaborative learning in an undergraduate sociological theory course. Teach. Sociol. 2010, 38, 197-206. [CrossRef]

43. Pastrana, L.M. Knowledge of learning styles. Obligatory starting point for teaching social science in general and the sociology of education in particular. Int. J. Learn. 2009, 16, 155-167.

44. Trowler, P.R. A sociology of teaching, learning and enhancement: Improving practices in higher education. Pap. Rev. Sociol. 2005, 76, 13-32. [CrossRef]

45. Bryan, A. The sociology classroom as a pedagogical site of discomfort: Difficult knowledge and the emotional dynamics of teaching and learning. Ir. J. Sociol. 2016, 24, 7-33. [CrossRef]

46. Santos, A.I.; Serpa, S. The importance of promoting digital literacy in higher education. Int. J. Soc. Sci. Stud. 2017, 5, 90-93. [CrossRef]

47. Murray, M.C.; Pérez, J. Unravelling the digital literacy paradox: How higher education fails at the fourth literacy. Issues Informing Sci. Inf. Technol. 2014, 11, 85-100. [CrossRef]

48. Sparks, J.R.; Katz, I.R.; Beile, P.M. Assessing Digital Information Literacy in Higher Education: A Review of Existing Frameworks and Assessments with Recommendations for Next-Generation Assessment; Research Report No. RR-16-32; Educational Testing Service: Princeton, NJ, USA, 2016.

49. Akbar, M. Digital technology shaping teaching practices in higher education. Front. ICT 2016, 3, 1-5. [CrossRef]

50. Carlin, A.P. The corpus status of literature in teaching sociology: Novels as "sociological reconstruction". Am. Sociol. 2010, 41, 211-231. [CrossRef]

51. Flores, M.A.; Simão, A.M.V.; Albuquerque, T.; Parente, C.; Barros, A.; Flores, P. Melhorar as aprendizagens através da avaliação: $O$ potencial dos métodos centrados nos alunos no contexto do ensino superior [Improving learning through assessment: The potential of student-centred methods in the context of higher education]. In Ministério da Educação e Ciência. Experiências de Inovação Didática no Ensino Superior [Ministry of Education and Science. Experiences of Didactic Innovation in Higher Education]; Governo de Portugal, Secretário de Estado do Ensino Superior: Lisbon, Portugal, 2015; pp. 211-228.

52. Hill, A.; Arford, T.; Lubitow, A.; Smollin, L.M. "I'm ambivalent about it": The dilemmas of PowerPoint. Teach. Sociol. 2012, 40, 242-256. [CrossRef]

53. Auken, P.V. Maybe it's both of us: Engagement and learning. Teach. Sociol. 2011, 41, 207-215. [CrossRef]

54. Purcell, D. Sociology, teaching, and reflective practice: Using writing to improve. Teach. Sociol. 2013, 41, 5-19. [CrossRef]

55. Williams, L.; Nixon, S.; Hennessy, C.; Mahon, E.; Adams, G. Inspiring to inspire: Developing teaching in higher education. Cogent Educ. 2016, 3, 1-12. [CrossRef] 
56. Moreira, G.; Pinheiro, M.M.; Simões, A.R. Pensar e partilhar práticas de qualidade no ensino superior [Thinking and sharing quality practices in higher education]. In Ministério da Educação e Ciência. Experiências de Inovação Didática no Ensino Superior [Ministry of Education and Science. Experiences of Didactic Innovation in Higher Education]; Governo de Portugal, Secretário de Estado do Ensino Superior: Lisbon, Portugal, 2015; pp. 97-116.

57. Ministério da Educação e Ciência. Experiências de Inovação Didática no Ensino Superior [Experiences of Didactic Innovation in Higher Education]; Governo de Portugal, Secretário de Estado do Ensino Superior: Lisbon, Portugal, 2015.

58. Salmon, G.; Wright, P. Transforming future teaching through 'Carpe Diem' learning design. Educ. Sci. 2014, 4, 52-63. [CrossRef]

59. Hedden, M.K.; Worthy, R.; Akins, E.; Slinger-Friedman, V.; Paul, R.C. Teaching sustainability using an active learning constructivist approach: Discipline-specific case studies in higher education. Sustainability 2017, 9, 1320. [CrossRef]

60. Walder, A.M. Pedagogical innovation in Canadian higher education: Professors' perspectives on its effects on teaching and learning. Stud. Educ. Eval. 2017, 54, 71-82. [CrossRef]

61. Alhija, F.N.-A. Teaching in higher education: Good teaching through students' lens. Stud. Educ. Eval. 2017, 54, 4-12. [CrossRef]

62. Sadler, I. The role of self-confidence in learning to teach in higher education. Innov. Educ. Teach. Int. 2013, 50, 157-166. [CrossRef]

63. Guzmán-Valenzuela, C. Challenging frameworks for understanding teaching practices in higher education: The end or the beginning? Qual. Res. Educ. 2013, 2, 65-91. [CrossRef]

(C) 2017 by the authors. Licensee MDPI, Basel, Switzerland. This article is an open access article distributed under the terms and conditions of the Creative Commons Attribution (CC BY) license (http:/ / creativecommons.org/licenses/by/4.0/). 